\title{
Economic viability of the third milking in systems of production using closed-circuit mechanical milking ${ }^{1}$
}

\author{
Marcos Aurélio Lopes ${ }^{2}$, Tatiane Mendonça Nogueira ${ }^{3}$, Gastão Lemos Barbosa \\ http://dx.doi.org/10.1590/0034-737X201461040014
}

\begin{abstract}
This study aimed to analyze the economic viability of the third milking in production systems using mechanical milking in a closed circuit, aiming to provide technicians and farmers with information to assist them in decisionmaking. Specifically, it intended: (a) to estimate the cost of one milking; (b) to estimate the cost of the third milking; (c) to develop a mathematical equation to estimate the minimum amount of milk produced with two milkings, from which it would be economically feasible to do the third milking. Data were collected from three dairy farms, from November 2010 to March 2011, keeping a twice-a-day milking frequency, with three data collections in each farm, totalizing nine collections. Considering the average data, it would be feasible to do the third milking if the average milk yield per day of lactating cows in a twice-a-day milking frequency was greater than or equal to $24.43 \mathrm{~kg}$ of milk.
\end{abstract}

Key words: dairy cattle, production cost, economy, milking frequency.

\section{RESUMO}

\section{Viabilidade econômica da terceira ordenha em sistemas de produção de leite com ordenhadeira de circuito fechado}

Objetivou-se, com este trabalho, analisar a viabilidade econômica da terceira ordenha, em sistemas de produção de leite com ordenhadeira mecânica, do tipo circuito fechado, visando a fornecer aos técnicos e pecuaristas informações que os auxiliem nas tomadas de decisões. Especificamente, pretendeu-se, ainda: a) estimar o custo de uma ordenha; b) estimar o custo da terceira ordenha; c) desenvolver uma equação matemática que permita estimar a quantidade mínima de leite produzida em duas ordenhas, a partir da qual será viável economicamente a realização da terceira ordenha. Os dados foram coletados em três propriedades leiteiras, de novembro de 2010 a março de 2011, em uma rotina de duas ordenhas diárias, sendo realizadas três coletas de dados em cada uma, perfazendo um total de nove. Considerando-se os dados médios, seria viável a realização da terceira ordenha se a produtividade média diária das vacas em lactação, em duas ordenhas, fosse igual ou superior a $24,43 \mathrm{~kg}$ de leite.

Palavras-chave: bovinocultura leiteira, custo de produção, economia, frequência de ordenhas.

\footnotetext{
Received: 13/02/2012; Approved: 17/07/2013.

${ }^{1}$ Research funded by FAPEMIG (CVZ APQ - 02490-10).

${ }^{2}$ Bachelor in Agricultural Science, Doctor of Science. Departamento de Medicina Veterinária, Universidade Federal de Lavras, Campus da UFLA, Caixa Postal 3037, 37200-000 Lavras, Minas Gerais, Brasil. malopes@dmv.ufla.br (corresponding author).

${ }^{3}$ Undergraduate in Veterinary Medicine. Departamento de Medicina Veterinária, Universidade Federal de Lavras, Campus da UFLA, Caixa Postal 3037, 37200-000 Lavras, Minas Gerais, Brasil. tati.mn@hotmail.com

${ }^{4}$ Veterinarian. Departamento de Medicina Veterinária, Universidade Federal de Lavras, Campus da UfLA, Caixa Postal 3037, 37200-000 Lavras, Minas Gerais, Brasil. gastaovet@hotmail.com
} 


\section{INTRODUCTION}

Many dairy farmers use the third milking as a way to reduce average fixed cost and increase milk production, thus optimizing farm operations.

A number of studies demonstrated the advantages and disadvantages of this practice, including increase in milk production (Amos et al., 1985; DePeters et al., 1985; Bar-Peled et al., 1995; Alves, 2004; Negrão, 2004; Dahl, 2005; Gama \& Lopes, 2008; Bernier-Dodier et al., 2010), changes in milk composition (Waterman et al., 1983; Amos et al., 1985; DePeters et al., 1985; Allen et al., 1986; Klei et al., 1997), effect on cow health and reproduction (Jarrett, 1977; Logan et al., 1978; Poole, 1982; DePeters et al., 1985; Allen et al., 1986; Moya et al., 2008) and feed intake and metabolism (Kelly et al., 1998; Smith et al., 2002). However, none addressed the issue of economic viability. Only a few researchers pointed out that increasing the milking frequency results in additional costs with feed, labor, milking machinery, implements and supplies (teat dip and cleaning solutions, paper towels, water, etc.) (Erdman \& Varner, 1995; Hebert, 2002; Dahl, 2005). The advantages of the third milking are the increase in milk production (Gama \& Lopes, 2008), reduction of fixed costs, improved udder health by reducing contaminants and better monitoring of mastitis, which improves management (Amos et al. 1985). The disadvantages of the third milking relate to increase in production cost, problems with labor by increasing an extra shift, shortening of rest period and feeding time because of the number of visits to the barn, increase in hoof problems because of the number of visits to the milking parlor, increase in concentrate feeding and teats more prone to wounds and traumas (Erdman \& Varner, 1995).

It is worth noting that the more time cows spend in the milking parlor, the less time they have to feed and rest, which are essential activities to maintain high performance. Factors such as increase in time of milking and distance traveled to the parlor may cause a significant increase in the requirements for maintenance of cows (Dahl, 2005). Therefore, research is needed for examining carefully the advantages and disadvantages or limitations cited in the literature.

The few studies on cost data only lists items that will be spent, without answering questions related to the costs and the economic viability of the third milking and not providing the farmers with reliable basis for appropriate decision-making. It is very clear the lack of information in dairy farms, with consequent wrong implementation of the third milking, often leading to the undercapitalization of the farm in the medium term.

Because of the importance of the subject for the dairy cattle industry and the lack of information available to farmers, we decided to study the economic viability of the third milking in production systems using mechanical milking in a closed circuit. We discuss the advantages and limitations of this practice aiming to assist technicians and farmers in the decision-making process. Specifically, we intended a) to estimate the cost of one milking; (b) to estimate the cost of the third milking; (c) to develop a mathematical equation to estimate the minimum amount of milk produced with two milkings, from which it would be economically feasible to do the third milking.

\section{MATERIALS AND METHODS}

Data were collected from three dairy farms keeping a frequency of twice-a-day milking, with three data collections in each farm, totalizing nine collections, from November 2010 to March 2011. Table 1 describes the characteristics of the three selected dairy farms. Farms 1 and 3 are located in the municipality of Boa Esperança, southern Minas Gerais. These farmers use the semiconfinement rearing system and hired labor, with medium technology level. The time cows spend in transit to and from the stalls is short because they are located near the milking parlor. Farm 2 is located in the municipality of Lavras. This farmer uses the semi-intensive rearing system and hired labor, with low technology level.

The quantities of products used (pre and post-dipping products, oil for vacuum pump, paper towels, acid, alkaline and neutral detergents, soap and hypochlorite) with their specifications were recorded to ensure more precise budgeting and accuracy of milking cost estimation. The electricity consumption per milking was also estimated, which was equal to the sum of consumption of lamps, electric vacuum pump motor, water heater and other items.

Prices were surveyed for all necessary materials and equipment used in the milking process, including: milk bucket, black cup, cart for carrying milk can, milk strainer, hygiene cup, rope, hoe and metal rake for removing manure, rotary flue brushes, pulsator filter, teat cups, lamps (milking parlor, machine and milk rooms, and corral), brass milk can, milk pipelines (long and short) and vacuum pipes (long and short), electric motor belt, apron, broom, rubber boots (for milkers), gloves and other items that were specific to each farm. The survey of these materials was used to estimate depreciation by the straight-line method, which is calculated by taking the purchase price of a product and dividing by its useful life.

To calculate the cost of labor, the milker's work time was recorded from when the cows were brought from pasture until the end of the milking routine, when cows were returned to pasture.

All data was recorded in a spreadsheet developed especially for this research, which shows the product name 
and specification, unit value, amount used and the total spending $(\mathrm{R} \$)$ of each product. From the sum of all expenses, we obtained the total operating cost of milking $(\mathrm{R} \$)$ and the means and standard deviations, per farm, per cow and per liter of milk.

We developed a second worksheet with the average operating cost per milking of the three farms to estimate the additional operating cost of the third milking, including the additional costs of electricity, labor and the usual expenses.

To implement the third milking, a third shift of work is required for the farm employees (without hiring new workers), which adds to the expenses the overtime payments (50\% more than ordinary hours of work), paid weekly rest, vacation, holidays, $13^{\text {th }}$ month salary, onethird vacation bonus, welfare, Time of Service Guarantee Fund (FGTS), the workers compensation insurance, education allowance, National Rural Apprenticeship Service (SENAR), National Institute of Colonization and Agrarian Reform (INCRA), Brazilian Service of Support for Micro and Small Enterprises (SEBRAE). These expenses account for $36.8 \%$ of the labor cost, in addition to extra pay for working night shifts, which in rural areas is $25 \%$ surcharge on the ordinary hours (Martins, 2008), because one of the milkings will be held between 10 p.m. and 6 a.m.. To calculate the additional cost of labor, we considered the time spent in one milking and, based on this cost, the cost of overtime plus extra pay for night shifts and applicable labor charges, which were added to the cost of ordinary hours of work. Thus, the additional labor cost was $\mathrm{R} \$ 5.64$ per extra night hour $(75.3 \%$ increase upon ordinary hours), which was added to the ordinary hours worked. In this study, the total labor cost was based on the FGTS and charges related to the employee's full salary and allowances. The base salary was set at $\mathrm{R} \$$ 545.00 .

To estimate the additional cost of electricity, the time spent in one milking was considered and that all the lamps in the milking parlor and milk room would be switched on, since the third milking should be done at nighttime. By knowing the wattage of each lamp, the consumption in $\mathrm{Kw} / \mathrm{h}$ was calculated by multiplying this power in watts by the number of usage hours and dividing by 1000 watts per kilowatt. This figure was multiplied by the price of a
$\mathrm{Kw} / \mathrm{h}$ in the countryside $(\mathrm{R} \$ 0.220330)$ and then by the number of lamps lit during milking. The costs of energy expended by the vacuum pump electric motor and the water heater, when it was used for washing the milking machine at the end of the routine, were also calculated.

Additional feed costs were not calculated because this study aims to estimate the cost of one milking routine, not considering other types of costs. We used the methodology of Operating Cost proposed by Matsunaga et al. (1976) to estimate costs. Data were compared using descriptive analysis with the MS Excel ${ }^{\circledR}$ application and arranged in tables for comparison, discussion and presentation of results (Lopes et al., 2009).

The economic viability of the third milking in the herds studied was obtained by a mathematical equation, which estimates the minimum production required for the third milking to be economically feasible.

In this study, the increase of $16.75 \%$ in milk production, by implementing the third milking, was obtained by averaging the estimates reported by several researchers (Vasconcellos, 1975; Amos et al., 1985; Bar-Peled et al., 1995; Erdman \& Varner, 1995; Hebert, 2002; Caminha \& Gonçalves, 2003; Alves, 2004; Negrão, 2004; Dahl, 2005; Dias, 2005; Gama \& Lopes, 2008).

\section{RESULTS AND DISCUSSION}

The total operating cost (TOC) to perform one milking using a closed-circuit milking machine was $\mathrm{R} \$ 29.69$ ( \pm 2.25$)$ (Table 2) for 45 cows (average number of cows of the three farms), corresponding to the sum of expenses with materials and equipment ( $\mathrm{R} \$ 1.24)$, which do not vary per milking, with those that vary $(\mathrm{R} \$ 28.45)$. Labor was the most representative item for TOC, followed by the materials used in the milking parlor for the cleaning and disinfection (post-dipping products, alkaline detergent, paper towels, neutral detergent) and equipment depreciation. In the latter group, the most representative items were the milking equipment and teat cups. These expenses are essential in order to the farmer to deliver good quality milk. Maintaining the equipment and materials in good condition, including milk and vacuum pipes and teat cups, is extremely important. Milk pipelines must be replaced every year and vacuum pipes every two years or when

Table 1. Characteristics of the three selected dairy farms (DF)

\begin{tabular}{lcccrc}
\hline Description & F 1 & F 2 & F 3 & Average & S D \\
\hline Number of cows milked & 71 & 30 & 35 & 45.3333 & 22.3681 \\
Breed & $\mathrm{GH}$ & $3 / 4 \mathrm{HPB}$ & $7 / 8 \mathrm{HPB}$ & & \\
Production of milk/day (kg) & 1.802 .3333 & 338.0000 & 624.0000 & 921.4444 & 776.1590 \\
Yield (kg) & 25.2663 & 11.1428 & 17.6603 & 18.0231 & 7.0687 \\
Average price of milk per liter $(\mathrm{R} \$)$ & 0.7600 & 0.7200 & 0.7600 & 0.7466 & 0.0230 \\
\hline
\end{tabular}

$\mathrm{SD}=$ standard deviation; 1 US\$ = R\$ 1.59; HPB: Black and white Holstein; GH; Crossbred Gir X Holstein. 
defective; while teat cups must be replaced every 2500 milkings or six months of use (Cardoso \& Costa, 2004). If these parts are defective or in poor condition, there will be repercussions on good hygiene, milk quality and health of cows, increasing the risk of mastitis infection.

A good pre-dipping technique is also important to produce quality milk, because without disinfecting the teats or when it is badly done, contamination will increase for both the milk, by contact with the contaminated teat and total bacterial count (TBC), and the udder, by enhancing the cases of mastitis and somatic cell count (SCC).

The materials used in the milking parlor and teat cup replacement are essential for improving milk quality and meeting the provisions of the Normative Instruction IN 51 (Published in the Official Gazette of 20/09/2002, Section 1, Page13 ) (Brazil, 2002). Thus, according to Demeu et al. (2011), the farmer will receive the bonus practiced by many dairy industries. Smith et al. (1998) studied outbreaks of mastitis in dairy cows and concluded that a hygiene program during milking is fundamental, because contamination occurs mostly at that time. Neave et al. (1966) highlighted that the incidence of intramammary infection is correlated with the amount of mastitis pathogens colonizing the teat end. Therefore, the way teats are clean is crucial to prevent the occurrence of mastitis (Brito \& Bressan, 1996). Rasmussen et al. (1991) discussed that the pre-milking disinfection can stimulate milk ejection and decrease the amount of bacteria in milk and teats. Prior teat disinfection, besides preventing diseases such as mastitis, plays an important role in the microbiological quality of milk. According to Amaral et al. (2004), prior disinfection of teats, milker's hands and milking parlor are very important to reduce the amount of pathogenic micro-organisms in milk and also to improve its hygienic conditions.

Prevention is a factor that must receive great attention from technicians and farmers. Demeu et al. (2011) estimated the economic impact of mastitis and pointed out that the prevention costs are small when compared with those of the curative treatment, in addition to losses by reduction in production and disposal of milk. These costs show how important are both the investment and adoption of preventive measures, which include not only the preventive treatments, as well as milking management practices and hygienic conditions in the facilities to reduce new infections. Lopes et al. (2004) observed that this practice has been neglected by many farmers. These researchers surveyed all actual operating costs of 16 dairy farms in southern Minas Gerais and found no purchases of pre and post-dipping solutions, acid and alkali detergents, paper towels, disinfectants and other milking products, in $50 \%$ of them.

Table 2. Total Operating Cost (TOC) of performing one milking in 45 cows using a closed-circuit milking machine

\begin{tabular}{|c|c|c|c|c|}
\hline \multicolumn{5}{|c|}{ Materials and Equipment } \\
\hline Item & $\begin{array}{c}\text { Average value } \\
\text { (R\$) }\end{array}$ & $\begin{array}{c}\text { Depreciation } \\
\text { average/mil } \\
(\mathbf{R} \$)\end{array}$ & $\%$ of item & $\%$ of total \\
\hline Milking parlor & 15.815 .1166 & 1.0718 & 86.4011 & 3.6098 \\
\hline Machine room & 10.7900 & 0.0095 & 0.7664 & 0.0319 \\
\hline Milk room & 1.8333 & 0.0045 & 0.3673 & 0.0151 \\
\hline Others & 19.9400 & 0.1546 & 12.4652 & 0.5207 \\
\hline Subtotal per milking & & 1.2405 & 100.0000 & 4.1780 \\
\hline Subtotal per cow & & 0.0271 & & \\
\hline Subtotal per kg milk & & 0.0013 & & \\
\hline \multicolumn{5}{|c|}{ Consumable Items } \\
\hline & Mean (R\$) & DP & $\%$ of item & $\%$ of total \\
\hline Milking parlor & 4.4999 & 3.7443 & 15.8168 & 15.1560 \\
\hline Machine room & 0.0338 & 0.0586 & 0.1119 & 0.1114 \\
\hline Electricity & 5.6074 & 3.0769 & 19.7098 & 18.8863 \\
\hline Labor & 18.3088 & 1.5226 & 64.3543 & 61.665 \\
\hline Subtotal per milking & 28.4501 & 2.2576 & 100.0000 & 95.8216 \\
\hline Subtotal per cow & 0.6229 & 0.2355 & & \\
\hline Subtotal per kg milk & 0.0308 & 0.0313 & & \\
\hline \multicolumn{5}{|c|}{ Overall Total } \\
\hline TOC /milking (R\$) & 29.6907 & 2.2576 & & 100.0000 \\
\hline TOC /cow (R\$) & 0.7304 & 0.2478 & & \\
\hline $\mathrm{TOC} / \mathrm{kg}$ milk $(\mathrm{R} \$)$ & 0.0490 & 0.0328 & & \\
\hline
\end{tabular}

$\mathrm{SD}=$ standard deviation; 1 US\$ $=\mathrm{R} \$ 1.59 ;$ Mil = milking. 
The main way to reduce the impact of depreciation of milking equipment and utensils is to increase the production scale.

The total operating cost of the third milking using a closed-circuit milking machine was $\mathrm{R} \$ 40.66$ (Table 3), in which $\mathrm{R} \$ 29.69$ is the cost of one milking carried out at daytime plus $\mathrm{R} \$ 10.97$, corresponding to the additional costs of labor $(\mathrm{R} \$ 10.82 ; 98.45 \%)$ and electricity $(\mathrm{R} \$ 0.16$; $1.45 \%)$.

There was a significant increase in spending on labor because implementing the third milking requires a third shift with overtime payments $(50 \%$ more than ordinary hours of work) and social charges. Thus, the additional cost of labor was R $\$ 5.64$ per overtime hour (an increase of $75.3 \%$ on ordinary hours).

If the farmer implements the third milking, there will also be an increase in concentrate feed consumption. Lopes et al. (2004) found the total feed cost reaching up to $60 \%$ of the actual operating costs, which is very important. Implementing the third milking results in an increase in milk production, hence the cow requirements for feed supplements also increases. If supplementation is not done correctly, cows will have to supply nutrients from their body reserves to support the increased production, leading to weight loss and body condition score loss, which harm the whole metabolism (Kelly et al. 1998; Smith et al., 2002).

Studies showed that improper feed management causes cows to compensate for the higher milk production and can result in lower recovery of body condition throughout lactation (Kelly et al., 1998; Smith et al., 2002). A well-balanced diet is essential to meet cow requirements and allow them the necessary intake for the recovery of body reserves throughout lactation. Providing complete diets with quality roughages several times a day is a nutritional management practice to help maximize the effect of feed and reduce the aforementioned problems. Cows milked more often have less time to feed, which further increases the importance of proper feed management.
Knowing the total operating cost of doing the third milking, we then need to know whether it is economically viable. To estimate the minimum amount of milk a cow produces per day in two milkings, so that there is economic feasibility in implementing the third milking, we developed Equation 1, using as base the equation of the equilibrium point or leveling point. That is, considering the contribution margin [milk selling price (MSP) minus average variable cost (VC)] and the cost of one milking (CM), we estimated the minimum amount of milk that pays for one milking. This amount was added to the daily production of the farm and the result was divided by the number of cows milked, to which was added the increase in milk production with the third milking. Therefore, the equation is a function of the farm's daily milk production in $\mathrm{kg}$, total operating cost of the third milking, price of $\mathrm{kg}$ of milk, average variable cost, number of cows milked and increase in daily milk production/day $(\mathrm{kg})$ from the implementation of the third milking.

$M P=\frac{\left(F P+\frac{T O C}{P M-V C}\right)}{N C} \times \frac{F P}{F P+I P} \quad$ (Equation 1),

where:

$\mathrm{MP}=$ Minimum milk production/day $(\mathrm{kg})$ to make the third milking economically viable.

$\mathrm{FP}=$ Farm's daily milk production $(\mathrm{kg})$.

TOC $=$ Total operating cost of the third milking $(\mathrm{R} \$)$.

$\mathrm{PM}=$ Price of $\mathrm{kg}$ of milk $(\mathrm{R} \$)$.

$\mathrm{VC}=$ Variable cost of one $\mathrm{kg}$ of milk produced in the farm $(\mathrm{R} \$)$.

$\mathrm{NC}=$ Number of cows milked per day

$\mathrm{IP}=$ Increase in daily milk production/day $(\mathrm{kg})$ with the third milking.

In this study, considering the average data collected in the three dairy farms using closed-circuit milking machines

Table 3. Total Operating Cost (TOC) of performing the third milking in 45 cows using a closed-circuit milking machine

\begin{tabular}{lcrr}
\hline Description & Value $(\mathbf{R} \$)$ & \% of additional cost & \% of TOC \\
\hline Additional cost of the third milking & 10.8166 & 98.5457 & 26.5980 \\
Labor & 0.1596 & 1.4542 & 0.3925 \\
Electricity & 10.9762 & 100.0000 & 26.9906 \\
\hline Total additional & & & 73.0094 \\
\hline Cost of one milking & 29.6907 & & 100.0000 \\
Total Operating Cost of milking & 40.6669 & & \\
TOC $(\mathrm{R} \$)$ & 0.9081 & & \\
TOC /cow $(\mathrm{R} \$)$ & 0.0452 & & \\
TOC $/ \mathrm{kg}$ milk $(\mathrm{R} \$)$ & & &
\end{tabular}

1US\$=R $\$ 1.59$ 
Table 4. Average daily values of herds of the studied farms

\begin{tabular}{lr}
\hline Description & Value \\
\hline Number of cows in lactation & \multicolumn{1}{c}{45.0} \\
Milk production $(\mathrm{kg})$ & 921.4444 \\
Average production/cow $(\mathrm{kg})$ & 18.0231 \\
Selling price/liter of milk $(\mathrm{R} \$)$ & 0.7466 \\
Operating cost of milk $(\mathrm{R} \$)$ & 0.6400 \\
Increase in production $(\%)$ & 16.7500 \\
\hline
\end{tabular}

(Table 4) and filling the Equation 1 with the respective values, the third milking would be feasible if the average daily milk yield of lactating cows were greater than or equal to $24.43 \mathrm{~kg}$ of milk (Figure 1). The farms studied had average daily yield of $18.02 \mathrm{~kg}( \pm 7.07) / \mathrm{cow}$ (Table 1$)$. With the increase of $16.75 \%$ (average of estimates reported by other researchers) obtained from the third milking, the yield would rise to 21.03 kilograms, which is $16.16 \%$ below the minimum required production to make the third milking economically feasible.

Filling the Equation 1 with data from each farm (Table 1), the minimum required production would be $25.55,21.97$ and $22.23 \mathrm{~kg}$ of milk for farms 1, 2 and 3, respectively, as in the following equations:

$M P=\frac{\left(1,802.33+\frac{47.54}{0.76-0.64}\right)}{71.00} \times \frac{1,802,33}{1,802.33+381.89} \quad($ Farm 1)

$\mathrm{MP}=25.55 \mathrm{~kg}$ of milk.

$M P=\frac{\left(338.00+\frac{34.52}{0.72-0.64}\right)}{30.00} \times \frac{338.00}{338.00+56.61} \quad($ Farm 2)

$\mathrm{MP}=21.97 \mathrm{~kg}$ of milk.

$M P=\frac{\left(642.00+\frac{31.99}{0.76-0.64}\right)}{35.00} \times \frac{642.00}{642.00+107.53} \quad($ Farm 3) $\mathrm{MP}=22.23 \mathrm{~kg}$ of milk.

On the basis of the estimates obtained from the three farms separately, it would be feasible for Farm 1 to implement the third milking and have its yield increased to $29.49 \mathrm{~kg}$, which would be $15.42 \%$ above the minimum milk production required to make the third milking economically viable; however, Farm 2 and Farm 3 would have yields of $13.00 \mathrm{~kg}$ and $20.61 \mathrm{~kg}$ of milk respectively, which would be below the minimum amounts of $21.97 \mathrm{~kg}$ (Farm 1) and $22.23 \mathrm{~kg}$ (Farm 2) required for economic feasibility.

Considering that the minimum milk production depends on the amount (in $\mathrm{kg}$ ) of milk produced each day in the farm, total operating cost of the third milking, selling price of $\mathrm{kg}$ milk, average variable cost of milk, number of cows milked and increase (in $\mathrm{kg}$ ) in daily milk production with the third milking (Equation 1 and Figure 1), dairy farmers have some options to reduce this value. The main option would be to increase the contribution margin, which is the difference between the milk selling price (MSP) and variable costs (VC).

Dairy farmers are price takers and are unable to affect the market price of milk, except when they produce larger amounts of milk of better quality and receive subsidies (Lopes et al., 2008). However, they can focus their management and/or technological efforts on reducing milk production costs (total, fixed, variable and operating) (Lopes et al, 2009). Reduction in variable costs will reduce the minimum milk production required to pay the costs of the third milking (TOC), which significantly influences the value estimated by Equation 1.

The second option would be to work with highproducing cows, as both the fixed costs $(4.17 \%)$ and the variable costs $(95.82 \%)$ (Table 2 ) of one milking (TOC in Equation 1) would be "diluted", further reducing the total cost of milk production, thus increasing the contribution margin. A higher production in two milkings implies greater amount resulting from increased percentage production, which in this research was $16.75 \%$.

A third option for small farmers would be the use of family labor, since, family workers are not paid overtime and extra pay for working night shifts, as well as there are no labor taxes paid by employers. The justification for this is that the cost of labor accounted for $98.54 \%$ of the additional costs and $26.59 \%$ of the total cost of doing the third milking (Table 3 ) due to costs related to overtime and night shift.

The fourth option would be to increase the number of cows, which would increase the production scale. Studies have shown that the production scale significantly impacts depreciation on fixed cost and total cost, by optimizing farm infrastructure, up to certain levels (Lopes et al., 2006).

$$
\begin{gathered}
M P=\frac{\left(F P+\frac{T O C}{P M-V C}\right)}{N C} \times \frac{F P}{F P+I P} \\
M P=\frac{\left(921.44+\frac{40.66}{0.74-0.64}\right)}{45.66} \times \frac{921.44}{921.44+154.34}
\end{gathered}
$$

$\mathrm{MP}=24.43 \mathrm{~kg}$ of milk

Figure 1. Example of application of the mathematical equation developed in this study.

Rev. Ceres, Viçosa, v. 61, n.4, p. 544-551, jul/ago, 2014 


\section{CONCLUSIONS}

Considering the average data collected in three dairy farms using closed-circuit milking machines, the implementation of the third milking will be feasible if the average daily yield of lactating cows is greater than or equal to $24.43 \mathrm{~kg}$ of milk. The average yield in these farms was $18.02 \mathrm{~kg} / \mathrm{milk} /$ day and the increased production by implementing the third milking would be equal to $21.03 \mathrm{~kg}$, resulting in it not being economically feasible to do the third milking

The mathematical equation developed in this study can help technicians and farmers to estimate the minimum amount of milk produced by a cow in two milkings, from which it will be economically feasible to do the third milking, with accuracy and considerable rapidity.

\section{ACKNOWLEDGEMENTS}

The authors want to thank the Research Foundation of the State of Minas Gerais (FAPEMIG) for the support given to this work and $\mathrm{CNPq}$ for granting the research productivity scholarship (FP II) to the first author.

\section{REFERENCES}

Allen DB, Depeters EJ \& Laben RC (1986) Three times a day milking: effects on milk production, reproductive efficiency, and udder health. Journal of Dairy Science, 69:1441-1446.

Alves M (2004) Robotização da ordenha em vacas leiteiras. Disponível em: <http://docentes.esa.ipcb.pt/bovinosdeleite/ aamalves.pdf $>$. Acessado em: 09 de setembro de 2009.

Amaral LA do, Isa H, Dias LT, Rossi Jr OD \& Nader Filho A (2004) Avaliação da eficiência da desinfecção de teteiras e dos tetos no processo de ordenha mecânica de vacas. Pesquisa Veterinária Brasileira, 24:173-177.

Amos HE, Kiser T \& Loewenstein M (1985) Influence of milking frequency on productive and reproductive efficiencies of dairy cows. Journal of Dairy Science, 68:732-739.

Bar-Peled U, Maltz E, Bruckental I, Folman Y, Kali Y, Gacitua H, Lehrer AR, Knight CH, Robinzon B, Voet H \& Tagari H (1995) Relationship between frequent milking or suckling in early lactation and milk production of high producing dairy cows. Journal of Dairy Science, 78:2726-2736.

Bernier-Dodier P, Delbecchi L, Wagner GF, Talbot BG \& Lacasse $P$ (2010) Effect of milking frequency on lactation persistency and gland remodeling in mid-lactation cows. Journal of Dairy Science, 93:555-564

Brasil (2002) Ministério da Agricultura, Pecuária e Abastecimento. Instrução Normativa $n^{\circ} 51$ de 20 de setembro de 2002. Aprova os Regulamentos Técnicos de Produção, Identidade e Qualidade do Leite tipo A, do leite tipo B, do leite tipo C, do leite Pasteurizado e do leite Cru Refrigerado e o Regulamento Técnico da Coleta de Leite Cru Refrigerado e seu Transporte a Granel. Diário Oficial da União, Brasília, p. 13, 20 set. 2002. Seção 1.

Brito JRF \& Bressan M (1996) Controle integrado da mastite bovina. Coronel Pacheco, Embrapa-CNPGL. 111p.
Caminha FO \& Gonçalves A de C (2003) Quando aumentar o número de ordenhas. Disponível em: <http:// w w w. m i $1 \mathrm{k} \mathrm{p} \mathrm{o} \mathrm{i} \mathrm{n} \mathrm{t.} \mathrm{c} \mathrm{o} \mathrm{m.} \mathrm{b} \mathrm{r} \mathrm{/} \mathrm{?} \mathrm{n} \mathrm{o} \mathrm{t} \mathrm{i} \mathrm{c} \mathrm{i} \mathrm{a} \mathrm{I} \mathrm{D}$ $=8713 \&$ act $\mathrm{A}=7 \&$ areaID $=61 \&$ secaoID $=159>$. Acessado em: 09 de setembro de 2009.

Cardoso I dos S \& Costa US (2004) Ordenha mecânica. $2^{\text {a }}$ ed. Brasília, SENAR. 36p.

Dahl GE (2005) Frequent milking in early lactation: considerations for implementation. In: 42 Florida Dairy Production Conference, Gainesville. Proceedings, University of Florida. p.7-12.

Demeu FA, Lopes MA, Costa GM da, Rocha CMBM da, Santos G dos \& Franco Neto A (2011) Influência do descarte involuntário de matrizes no impacto econômico da mastite em rebanhos leiteiros. Ciência e Agrotecnologia, 35:195-202.

Depeters EJ, Smith NE \& Acedo-Rico J (1985) Three or two times daily milking of older cows and first lactation cows for the entire lactations. Journal of Dairy Science, 68:123-132.

Dias HS (2005) Ordenhar: quantas vezes por dia? Disponível em: $<\mathrm{ht} \mathrm{tp://www.rehagro.com.br/siterehagro/}$ publicacao.do?cdnoticia=722>. Acessado em: 09 de setembro de 2009.

Erdman RA \& Varner M (1995) Fixed yield responses to increased milking frequency. Journal of Dairy Science, 78:1199-1203.

Gama MAS \& Lopes FCF (2008) Alteração da frequência de ordenha: aspectos produtivos e econômicos. Revista DBO Mundo do Leite, 29:17-19.

Hebert C (2002) Never 2 without 3? Impact of the increase of milking frequency. Producteur-de lai-Quebecois, 23:22-25.

Jarrett JA (1977) See better udder health with $3 \times$ milking. Hoard's Dairyman, 122:86.

Kelly AL, Reid S, Joyce P, Meaney WJ \& Foley J (1998) Effect of decreased milking frequency of cows in late lactation on milk somatic cell count, polymorphonuclear leucocyte numbers, composition, and proteolytic activity. Journal of Dairy Research, 65:365-373.

Klei LR, Lynch JM, Barbano DM, Bandler DK, Oltenacu PA \& Lednor AJ (1997) Influence of milking three times a day on milk quality. Journal of Dairy Science, 80:427-436.

Logan TR, Armstrong DV \& Selley RA (1978) Three times a day milking. Tucson, University of Arizona. 8p.

Lopes MA, Lima ALR, Carvalho F de M, Reis RP, Santos IC \& Saraiva FH (2006) Efeito da escala de produção nos resultados econômicos de sistemas de produção de leite na região de Lavras (MG): um estudo multicasos. Boletim da Indústria Animal, 63:177-188.

Lopes MA, Lima ALR, Carvalho F de M, Reis RP, Santos IC \& Saraiva FH (2004) Efeito do tipo de sistema de criação nos resultados econômicos de sistemas de produção de leite na região de Lavras, MG. Ciência e Agrotecnologia, 28:1177-1189.

Lopes MA, Dias AS, Carvalho F de M, Lima ALR, Cardoso MG \& Carmo EA do (2009) Resultados econômicos de sistemas de produção de leite com diferentes níveis tecnológicos na região de Lavras-MG nos anos 2004 e 2005. Ciência e Agrotecnologia, $33: 252-260$

Lopes MA, Cardoso MG, Carvalho F de M, Lima ALR, Dias AS \& Carmo EA do (2008) Efeito da escala de produção nos resultados econômicos de sistema de produção de leite na região de Lavras (MG) em 2004 e 2005. Archivos Latinoamericanos de Producción Animal, 16:121-129.

Martins E (2008) Contabilidade de custos. 9a ed. São Paulo, Atlas. $378 \mathrm{p}$. 
Matsunaga M, Bemelmans PF, Toledo PEN de, Dulley RD, Okawa H \& Pedroso IA (1976). Metodologia de custo de produção utilizado pelo IEA. Agricultura em São Paulo, 23:123-139.

Moya SL, Gómez MA, Boyle LA, Mee JF, O’Brien B \& Arkins S (2008) Effects of milking frequency on phagocytosis and oxidative burst activity of phagocytes from primiparous and multiparous dairy early lactation. Journal of Dairy Science, 91:587-595.

Neave FK, Dood FH \& Kingwill RG (1966) A method of controlling udder disease. The Veterinary Record, 78:521-523.

Negrão JA (2004) Manejo para produção de leite de alta qualidade. Aspectos fisiológicos relacionados à síntese e ejeção do leite. In: Zootec, Brasília. Anais, Fapesp. p.1-7.

Poole DA (1982) The effects of milking cows three times daily. Animal Production, 34:197-201.
Rasmussen MD, Galton DM \& Petersson LG (1991) Effects of premilking teat preparation on spores of anaerobies bacterias and iodine residues in milk. Journal of Dairy Science, 74:24722478 .

Smith JW, Ely LO, Graves WM \& Gilson WD (2002) Effect of milking frequency on DHI performance measures. Journal of Dairy Science, 85:3526-3533.

Smith TH, Fox LK \& Middleton JR (1998) Outbreak of mastitis caused by one strain of Staphylococcus aureus in closed dairy herd. Journal of the American Veterinary Medical Association, 212:553-556.

Vasconcellos PMB (1975) Conhecimentos gerais, ordenha: tipos de ordenha (manual e mecânica). In: Vasconcellos PMB (Ed.) Guia prático para o fazendeiro. $16^{\mathrm{a}}$ ed. São Paulo, Nobel. p.215232.

Waterman DF, Harmon RJ, Hemken RW \& Langlois BE (1983) Milking frequency as related to udder health and milk production. Journal of Dairy Science, 66:253-258. 